\title{
The relationship between education level, retirement status, and civic engagement among older adults in Indonesia
}

\author{
I Komang Winata ${ }^{1}$ \\ ${ }^{1}$ SMA Negeri 2 Mendoyo, Bali, Indonesia
}

\begin{abstract}
The Indonesian population is aging very rapidly, and as the number of old people increases, the number of retirees increases. Many scholars have argued the benefits of civic engagement in old age, but there is a lack of empirical evidence of the factors associated with it in Indonesia. This study aimed to investigate the association between education levels, retirement status, and civic engagement among older adults in Indonesia. The study used data from the fifth wave of the Indonesia Family, and Life Survey held in late 2014 and early 2015. The study included participants aged 56 years and older, the mandatory age for retirement in 2014. Multiple regression was modeled for data analysis. The main results revealed that those who completed junior and senior high school and high education exhibited more civic engagement than those who completed only primary education.Moreover, the study found that retired people were less engaged in civic activities than those still in the labor force. These relationships held even after controlling confounding variables. Education needs to be reemphasized to Strengthen democracy and growth, and there is a need for further investigation concerning retirement and civic engagement in Indonesia.
\end{abstract} Article History: Submitted : : 10-01-2021 Revised : :21-01-2021 Accepted : 06-02-2021

Keywords:

civic engagement, education level, retirement status

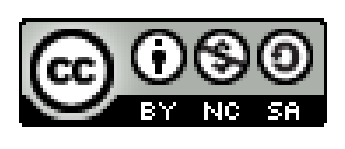

Cite in APA ${ }^{\text {7th: }}$

Winata, I. K. (2021). The relationship between education level, retirement status, and civic engagement among older adults in Indonesia. Jurnal Civics: Media Kajian Kewarganegaraan, 18(1), 38-48. https://doi.org/10.21831/JC.V1811.37612

\section{Introduction}

Countries worldwide are expecting an increased aging population because of the enhanced life expectancy and decline in fertility. For example, in the ASEAN region, it is estimated that by the year 2050, 24.2\% of the population will be old individuals (Adioetomo \& Mujahid, 2014). Indonesia is the most populous country globally and is estimated to have around 74 million aging people in the same year (Kadar et al., 2013). With the increase of aging individuals, the number of people retiring from the workplace increases as well. Retirees struggle to maintain social relations and struggle with integration (Young \& Glasgow, 1998). Having Withdrawn from work activities is more likely than retired individuals will find other forms of activities to participate in Van Den Bogaard et al., (2014) have found that retirees were keen to engage in civic activities. When engaging in civic activities, retirees remain physically active, which brings health benefits. Moreover, they expand their social world and engage in different forms of socialization, increasing the likelihood of getting social support. That might improve their mental health and social wellbeing. Seguin (1973) emphasized the importance of keeping social roles in retirement. They argued that since retirees lose significant workplaces, family, and other associations, they may try to find alternative community roles. In this perspective, civic engagement can present opportunities for retirees to regain social roles. Thus, the relationship between retirement and civic engagement is worth investigating. 
Putnam (1995) defined civic engagement as an interest of people willing to contribute to the community's improvements through activities, interest and willingness to engage in public affairs, and political elections participation. There is no common operationalization of civic engagement in the literature. Therefore, many researchers have used different indicators (Adler \& Goggin, 2005). Civic engagement can be measured through participation in social activities, including formal and informal, like volunteering in one's community or being a member of associations to improve neighborhoods (Diller, 2001). Other forms of civic engagement might include political activities like voting, being a member of a political party, or protesting (Keeter et al., 2002). Therefore, different studies come with different operationalization of civic engagement.

Civic engagement is usually taken as the 'heart of democracy' (Verba et al., 1995) because of the social skills, attitudes, opinions, and political stimuli citizens derive from social participation. Putnam (1993) found a direct relationship between social participation and democracy. Apart from its benefits for democracy in a country, civic engagement seems to yield health benefits and enhance overall well-being (Piliavin \& Siegl, 2007). Studies have shown that civic engagement enhances the health and quality of life of older adults by engaging in meaningful activities and social interaction. It is therefore essential to investigate factors associated with civic engagement. Among them, education has received much attention in the literature. Empirical studies have revealed a positive association between education and civic engagement (Nie et al., 1996; Verba et al., 1995). Moreover, it has been reported in a study that better-educated citizens were more likely to engage in civic and political activities (Larreguy \& Marshall, 2017). However, in an authoritarian regime, it was found that the more people were educated, the more they tended to disengage from civic and political activities (Croke et al., 2016), which was taken as a silent means to express their protest against the regime.

It is interesting to examine this association in Indonesia. Even though it is a young democracy, Indonesia succeeded in decentralizing the institutions by conferring local institutions' power (Lussier \& Fish, 2012). This decentralization of institutions gives a meaningful way to the citizen, which increases civic engagement. On the other side, it made education much more expensive (Lussier \& Fish, 2012), which presents difficulties in accessing education, especially in remote areas. Therefore, it is crucial to investigate the association between education level and civic engagement at the national level.

Although many studies have sought to investigate the links between education levels and civic engagement in the literature, few were conducted among the aging Indonesian population. They were adding that there is an upcoming increased aging population leading to an increased number of retirees. The present research aimed to examine the associations between education levels, retirement status, and civic engagement in Indonesia, using nationally representative data from the fifth wave of the Indonesia Family Life Survey.

\section{Methods}

The data used in this research come from the fifth wave of the Indonesia Family Survey (IFLS). IFLS is a longitudinal socioeconomic and health survey representing around $83 \%$ of the Indonesian population (Strauss et al., 2016). IFLS is conducted by Rand Corporation (California, US) in collaboration with the survey METER (Yogyakarta, Indonesia) since 1993 (Strauss et al., 2016). To collect data at the individual level, household level, and community level, this survey used multistage stratified sampling. The present study used the fifth wave of the survey as it is the most current wave available. The fifth wave collected data on 50,148 individuals from16,204 households and living in 13 provinces of Indonesia (Strauss et al., 2016). The mandatory age for 
retirement in 2014 was 56. Therefore this study used a sample of individuals 56 years old and over. After cleaning missing data for civic engagement, a sample of 5,257 old individuals was yielded. The respondents were informed about the survey's goals and outcome and gave their informant consent, and all the documentation can be found in (Strauss et al., 2016).

The independent variables in this study are levels of education and retirement status. The survey asked respondents questions about their education and retirement status. In this study, education was dummy coded based on the level of education completed by respondents; (1) for elementary school and equivalents, (2) for junior high school and equivalents, (3) for senior high school and equivalents, and 4 for high education. Sixty-seven percent of the respondents reported that they completed elementary school, $15 \%$ had completed junior high school, 13.8\% had completed senior high school, and $4.2 \%$ had achieved high education. For retirement status, a dummy code (1) was given to respondents who reported that they were retired and (0) to respondents still in the labor force. Of the respondents, $26.8 \%$ reported that they had retired from work, and 73.2 reported that they were still working.

This study's dependent variable was civic engagement and was operationalized through participation in community activities and voting. The survey asked the following questions: 1 ) During the last 12 months, did they participate in community activities, cooperatives, voluntary labor, program to improve the community/neighborhood, national program for community empowerment (PNPM), political parties? 2) Did they vote in the most recent for president and head of district (bupati/walikota) (Strauss et al., 2016)? With a yes or no option. The answers were then aggregated into one score, indicating the total number of activities a respondent participated in in the last 12 months. The overage score for civic engagement was 2.84 (SD=1.31, range $=0-8$ ). That shows that respondents exhibited shallow civic engagement. However, there must be other forms of civic engagement that were not used in this study. Given that there is no single operationalization of civic engagement in the literature, it is hard to come with a comprehensive measure to capture the whole concept.

There has been evidence of the relationships between gender, marital status, age, personality, religiosity, self-rated health, and civic engagement (Choi, 2003; Schmitt, 2010; WrayLake et al., 2019). Therefore, these confounding variables were included in the analysis.

Gender was coded with dummy variables (1) for male and (0) for female. Fifty-one and a half percent of respondents were male, and $48.5 \%$ were female. The mean age was 63.9 (SD=6.60, range $=56-90$ ). A dummy code (1) was given to married individuals and (0) for unmarried ones (single, widow, and divorced). Seventy-two percent were married, and $28 \%$ were not married. Religious individuals were given a dummy code (1) and (0) for not religious. More than $88 \%$ of respondents reported being religious. Extroversion was used to control for the personality traits of respondents. Personality traits were measured using a short version of the Big Five Inventory (Rammstedt \& John, 2007). The average score was $7.03(S D=1.32$, range=2-10). Self-rated health was entered into the analysis. Respondents were asked to rate their health on a scale from very healthy, somewhat healthy, somewhat unhealthy and very unhealthy (Strauss et al., 2016). Two categories were made. The respondents who reported that they were healthy and somewhat healthy were given the dummy code (1), and those who reported being somewhat unhealthy and very unhealthy were given (0). More than $65 \%$ reported being healthy.

A simple model (model 1) was first tested in which levels of education and retirement status were predictors of civic engagement. A set of other variables that have been found to be related to civic engagement were then included in model 2 to check whether controlling for these confounders impacted the association between education, retirement status, and civic 
engagement. Linear regression models were used to perform these analyses. This analysis estimates the association between the independent variables and the outcome variable, taking into account potential confounding variables. Both data management and analysis were performed using R statistical software (Fox \& Leanage, 2016).

\section{Result and Discussion}

This study used a quantitative approach to investigate the relationship between education level, retirement status, and civic engagement among older adults aged between 56 and 90 in Indonesia. The descriptive statistics sample found in Table 1 is the results of the multivariate analysis are summarized in Table 2.

The descriptive statistics for the variables are found in table 1.

Table 1

Descriptive statistics of the sample

\begin{tabular}{|c|c|c|c|c|c|c|c|}
\hline & Min & Max & Mean & SD & $\%$ & Mean (SD) & $\mathrm{n}$ \\
\hline Civic engagement & 0 & 8 & 2.84 & 1.31 & & & 5,257 \\
\hline Age & 56 & 90 & 63.9 & 6.60 & & & 5,257 \\
\hline Extroversion & 2 & 10 & 7.03 & 1.32 & & & 5,233 \\
\hline \multicolumn{8}{|l|}{ Gender } \\
\hline Female & & & & & 48.5 & $2.42(1.12)$ & 2,549 \\
\hline Male & & & & & 51.5 & $3.24(1.354)$ & 2,708 \\
\hline \multicolumn{8}{|l|}{ Education } \\
\hline Elementary school & & & & & 67 & $2.83(1.27)$ & 2,786 \\
\hline Junior high school & & & & & 15 & $3.04(1.44)$ & 621 \\
\hline Senior high school & & & & & 13.8 & $3.13(1.37)$ & 572 \\
\hline High education & & & & & 4.2 & $3.15(1.27)$ & 173 \\
\hline \multicolumn{8}{|l|}{ Marital status } \\
\hline Married & & & & & 72 & $2.98(1.32)$ & 3,791 \\
\hline Unmarried & & & & & 28 & $2.48(1.21)$ & 1,466 \\
\hline \multicolumn{8}{|l|}{ Retirement } \\
\hline Retired & & & & & 26.8 & $2.65(1.32)$ & 1,273 \\
\hline Non-retired & & & & & 73.2 & $3.00(1.31)$ & 3,466 \\
\hline \multicolumn{8}{|l|}{ Religiosity } \\
\hline Religious & & & & & 88.6 & $2.84(1.31)$ & 3,633 \\
\hline Non-religious & & & & & 11.4 & $2.77(1.34)$ & 466 \\
\hline \multicolumn{8}{|l|}{ Self-Rated Health } \\
\hline Healthy & & & & & 65.7 & $2.93(1.33)$ & 3,442 \\
\hline Unhealthy & & & & & 34.3 & $2.72(1.23)$ & 1,791 \\
\hline
\end{tabular}

Mean (SD): mean and standard deviation of civic engagement scores per categories

The multicollinearity test indicated minimal values for all the predictors (VIF between 1.03 and 1.46). That suggests there is no multicollinearity between the independent variables. Therefore, all the predictors were included in the multivariate analysis.

The multivariate analysis results, including model 1 and model 2 , are presented in table 2 . The first model indicated that those who completed junior high school, senior high school, and high education participated more in civic activities than those respondents who completed 
primary education ( $\beta=0.24, p<0.001, \beta=0.37, p<0.001, \beta=0.42, p<0.001$, respectively). Moreover, the simple model revealed that those who were retired participated less in civic activities than those who still in the labor force $(\beta=-0.33, p<0.001)$. The simple model explained $2 \%$ of the variance.

Model 2 added to model 1 a set of confounding variables. This model indicated that even after adjusting for control variables, the relationship between education and retirement status levels remained significant at $p<0.001$.

Table 2

Multivariate Regression Model Predicting Civic Engagement

\begin{tabular}{|c|c|c|c|c|}
\hline & Model 1 & & Model 2 & \\
\hline & Coef. & SE & Coef. & SE \\
\hline $\begin{array}{l}\text { Constant } \\
\text { Education } \\
\text { elementary }\end{array}$ & $2.98 * * *$ & 0.02 & $1.84^{* * *}$ & 0.30 \\
\hline Junior HS & $0.24 * * *$ & 0.06 & $0.14^{*}$ & 0.06 \\
\hline Senior HS & $0.37 * * *$ & 0.06 & $0.16^{*}$ & 0.07 \\
\hline $\begin{array}{l}\text { High Education } \\
\text { Retirement (ref. non- } \\
\text { retired) }\end{array}$ & $0.42 * * *$ & 0.10 & $0.24 *$ & 0.11 \\
\hline $\begin{array}{c}\text { Retired } \\
\text { Gender (ref. female) }\end{array}$ & $-0.33 * * *$ & & $-0.25 * * *$ & 0.25 \\
\hline Male & & & $0.61 * * *$ & 0.05 \\
\hline Age & & & 0.00 & 0.00 \\
\hline Marital (ref. unmarried) & & & & \\
\hline \begin{tabular}{l}
\multicolumn{2}{r}{ Married } \\
Religiosity (ref. non- \\
religious
\end{tabular} & & & $0.17^{* *}$ & 0.06 \\
\hline Religious & & & $0.15^{*}$ & 0.07 \\
\hline Extraversion & & & $0.04 *$ & 0.01 \\
\hline SRH (ref. unhealthy) & & & & \\
\hline Healthy & & & $0.13^{*}$ & 0.05 \\
\hline Adjusted R2 & 0.02 & & 0.08 & \\
\hline
\end{tabular}

${ }^{*} p<0.05,{ }^{* *} p<0.01, * * * p<0.001 ;$ SE: Standard Errors; SRH: self-rated health

Control variables exhibited significant association with civic engagement as well. There was a high difference between males and females in participating in civic engagement. Males participated more than females $(\beta=0.61, p<0.001)$. compared to unmarried, married individuals participated more in civic engagement $(\beta=0.17, p<0.01)$. Religious participants seemed more engaged than non-religious $(\beta=0.15, p<0.05)$. Moreover finally, extroverted and healthy individuals were more engaged in civic activities ( $\beta=0.04, p<0.05, \beta=0.13, p<0.05$, respectively).

This study aimed to investigate the association between levels of education, retirement status, and civic engagement in old age in Indonesia. The main findings revealed that education is related to civic engagement in that way that the more people are educated, the more they tend to be engaged in civic activities. Those who had completed junior high school, senior high school, and high education were more engaged in civic activities than those who had completed primary 
education. Moreover, this study found that retired individuals were less likely to engage in civic activities than those still in the labor force. These findings were still relevant even after adjusting for gender, age, marital status, religiosity, and self-rated health.

These findings align with prior studies that found a positive association between education and civic engagement (Barrios, 2017; Klesner, 2007). High levels of education were correlated with increased political and community participation in Nigeria (Larreguy \& Marshall, 2017). Egerton (2002) reported having found a moderate effect of high education on civic engagement using British panel data. There are some explanations of this relationship that can be provided. Education aims to equip students with a wide range of social, cognitive, and social skills, which are the prerequisites of effective citizenship (Emler \& Frazer, 1999). It has been argued that schooling provides civic skills (Verba et al., 1995).

Moreover, by providing knowledge, education knocks down civic engagement barriers (Carpini et al., 1996). All these findings are taken together to yield and confirm the benefits of education for a country. Another study found that civic education in universities impacted the value of defending a country, although this was in the form of thought and not actions (Dahliyana et al., 2020). It has been argued that education enables the processing of complex information and instructs on how people should act for the collective interests (Künkler \& Lerner, 2016). Moreover, education provides students with norms, responsibilities, and pluralistic values appropriate in a democratic society (Huang et al., 2009).

However, Croke et al., (2016) have argued that a variable has to be taken into account. Using the education reform in Zimbabwe, they found that in authoritarian electoral regimes, educated people were less likely to engage in civic and political activities. That was seen as a way to protect against the abusive regime. The relationship between education and civic engagement seems to be moderated by the regime style in a country. Future research should take this into account.

The findings of retirement status are somewhat a paradox. In retirement, people have enough time to devote to civic activities. The continuity theory (Atchley, 1999) posits that even though retirement leads to role loss, retirees can cope with the loss by making new roles. This study found that those who were retired were less likely to engage in civic activities than those who were still working. That is an interesting issue that needs further investigation. Prior studies have reported that retirees participated more in voluntary activities than those still working (Hank, 2011). In another study, it was found that older adults were more engaged in voluntary work (Choi, 2003). On the other side, a study found that the more retirees were engaged in community activities, the more likely they would be satisfied with retirement (Nizeyumukiza et al., 2020). The mechanisms by which retirees are less engaged than workers in Indonesia are not well addressed. When they retire, it possible that old individuals have to find other informal jobs to contribute to the family's financial subsistence. These informal jobs may be mostly manual and tiring, and given their old age, this may limit them from participating in civic activities. Future studies are encouraged to investigate this issue in depth.

Kaskie et al.,(2008) examined civic engagement as a retirement role. They compared retirees who were not engaged with retirees engaged in volunteer work or with paid work in organizations associated with civic engagement. They found that engaged and non-engaged retirees differed by factors like education level and views about volunteer work and job return. They reported that 
most disengaged retirees were unaware of volunteer opportunities in their communities. They concluded that spreading information about civic engagement in targeted media coupled with educational campaigns would increase civic engagement among retirees. Civic engagement presents an opportunity for retirees. Retirees need to remain active, and participating in community activities allows them to be active and contribute to their environments. Besides, community activities allow retirees to socialize, which might improve their mental health. A study investigates the factors associated with retirees' retirement satisfaction in Indonesia and found that participating in the community increased the odds of being satisfied with retirement (Nizeyumukiza et al., 2020).

Other findings concern control variables. This study found that being male, married, extroverted, religious, and healthy were associated with civic engagement. It was found that males were more engaged than females in Indonesia. Females may be more likely to be concerned with house chores while their male partners participate in community activities. Previous studies reported that females were more engaged in Australia's political activities (Miranti \& Evans, 2019). The study found that married individuals were more engaged in civic activities. That is in line with previous studies that have documented that married people yielded greater participation in activities than non-married and that being married increased the odds of voting in elections (Huyser et al., 2017). Religiosity was also found associated with civic engagement. That corroborates the results of prior studies that have reported the benefits of religiosity for civic engagement. In their study, Lewis et al., (2013) stated that the positive relationship between religiosity and civic engagement might be because religiosity increases sympathy in people and subsequently increases civic behavior to help others. A similar finding was also found in Indonesia. Pratono et al., (2019) found that respondents with high religiosity levels were more caring for patients who were suffering, although this civic behavior was less motivated by empathy. This study found that extroverted people exhibited willingly to civic participation. Previous studies reported a positive relationship between extroversion and civic participation (Omoto et al., 2010). As expected, healthy individuals were more engaged. It is also possible that civic activities yield health benefits (Milton et al., 2011; You et al., 2015). When participating in community activities, people stay active, but they also engage in socialization. The ties and friendship they make contribute to their overall well-being.

There are some limitations of this study that have to be mentioned. The data used was from the fifth wave and is cross-sectional. Therefore, causal effects cannot be made. Longitudinal studies may help address this issue. The strength of the study resides in the fact that the study used data with a national scope. Moreover, a set of potential confounding variables were entered into the analysis.

\section{Conclusion}

This study has confirmed the evidence that education is essential for civic engagement. Given the upcoming increased aging population in Indonesia, this study sought to investigate whether this association is still relevant even in old age. Levels of education seem to matter even in old age. Indonesia has managed to decentralize its institutions, including education. Efforts have to be increased in order to render education accessible in all areas of Indonesia. With the wellknown benefits of civic engagement to a country, education is still the angled stone to be 
strengthened. It was also found that old individuals who were still working participated more in civic activities than retired. Future studies have to address this issue, and all stakeholders should try to understand why retirees are less engaged in Indonesia. Retirees may spend much of their time watching television, which presents a negative and a positive side. The negative side is that by staying home watching television, the risk of getting physical and mental problems, including coronary diseases and depression, increases. The positive side is that television can be targeted as a medium to show retirees the benefits of engaging in community activities.

\section{Acknowledgment}

This study used data from $5^{\text {th }}$ wave of the Indonesia Family Life Survey. We are therefore thankful to rand corporation (https://www.rand.org/well-being/social-and-behavioralpolicy/data/FLS/IFLS/ifls5.html) who provided free access to the data and to the indonesian people who completed the survey.

\section{References}

Adioetomo, S. M., \& Mujahid, G. (2014). Indonesia on the threshold of population ageing (Vol. 1).

Adler, R. P., \& Goggin, J. (2005). What do we mean By "'civic engagement"”? Journal of Transformative Education, 3(3), 236-253. https://doi.org/10.1177/1541344605276792

Atchley, R. C. (1999). Continuity and adaptation in aging: Creating positive experiences. The John Hopkins University Press.

Barrios, J. J. (2017). Trust and civic engagement: Evidence from six Latin American cities. Journal of Trust Research, 7(2), 187-203. https://doi.org/10.1080/21515581.2016.1268966

Carpini, D., Michael, X., \& Keeter, S. (1996). What Americans know about politics and why it matters. Yale University Press.

Choi, L. H. (2003). Factors affecting volunteerism among older adults. Journal of Applied Gerontology, 22(2), 179-196. https://doi.org/10.1177/0733464803022002001

Croke, K., Grossman, G., Larreguy, H. A., \& Marshall, J. (2016). Deliberate disengagement: How education can decrease political participation in electoral authoritarian regimes. American Political Science Review, 110(3), 579-600. https://doi.org/10.1017/S0003055416000253

Dahliyana, A., Nurdin, E. S., Budimansyah, D., \& Suryadi, A. (2020). Pendidikan pendahuluan bela negara melalui pendidikan kewarganegaraan. Jurnal Civics: Media Kajian Kewarganegaraan, 17(2), 130-141. https://doi.org/10.21831/jc.v17i2.27919

Diller, E. (2001). Citizens in service: The challenge of delivering civic engagement training to national service programs. Corporation for National and Community Service.

Egerton, M. (2002). Higher education and civic engagement. The British Journal of Sociology, 53(4), 603-620. https://doi.org/10.1080/0007131022000021506

Emler, N., \& Frazer, E. (1999). Politics: The education effect. Oxford Review of Education, 25(1-2), 251-273. https://doi.org/10.1080/030549899104242

Fox, J., \& Leanage, A. (2016). R and the journal of statistical software. Journal of Statistical Software, 73(2), 1-13. https://doi.org/10.18637/jss.v073.i02

Hank, K. (2011). Societal determinants of productive aging: A multilevel analysis across 11 European countries. European Sociological Review, 27(4), 526-541. https://doi.org/10.1093/esr/jcq023 
Huang, J., Maassen van den Brink, H., \& Groot, W. (2009). A meta-analysis of the effect of education on social capital. Economics of Education Review, 28(4), 454-464. https://doi.org/10.1016/j.econedurev.2008.03.004

Huyser, K. R., Sanchez, G. R., \& Vargas, E. D. (2017). Civic engagement and political participation among American Indians and Alaska natives in the US. Politics, Groups, and Identities, 5(4), 642-659. https://doi.org/10.1080/21565503.2016.1148058

Kadar, K. S., Francis, K., \& Sellick, K. (2013). Ageing in Indonesia - Health status and challenges for the future. Ageing International, 38(4), 261-270. https://doi.org/10.1007/s12126-0129159-y

Kaskie, B., Imhof, S., Cavanaugh, J., \& Culp, K. (2008). Civic engagement as a retirement role for aging Americans. Gerontologist, 48(3), 368-377. https://doi.org/10.1093/geront/48.3.368

Keeter, S., Zukin, C., Jenkins, K., \& Jenkins, K. (2002). The civic and political health of the nation: A generational portrait. Center for Information and Research on Civic Learning and Engagement (CIRCLE), School of Public Policy, University of Maryland.

Klesner, J. L. (2007). Social capital and political participation in latin America: Evidence from Argentina, Chile, Mexico, and Peru. Latin American Research Review, 42(2), 1-32. https://doi.org/10.1353/lar.2007.0022

Künkler, M., \& Lerner, H. (2016). A private matter? Religious education and democracy in Indonesia and Israel. British Journal of Religious Education, 38(3), 279-307. https://doi.org/10.1080/01416200.2015.1113933

Larreguy, H., \& Marshall, J. (2017). The effect of education on civic and political engagement in nonconsolidated democracies: Evidence from Nigeria. The Review of Economics and Statistics, 99(3), 387-401. https://doi.org/10.1162/REST_a_00633

Lewis, V. A., MacGregor, C. A., \& Putnam, R. D. (2013). Religion, networks, and neighborliness: The impact of religious social networks on civic engagement. Social Science Research, 42(2), 331346. https://doi.org/10.1016/j.ssresearch.2012.09.011

Lussier, D. N., \& Fish, M. S. (2012). Indonesia: The benefits of civic Engagement. Journal of Democracy, 23(1), 70-84. https://doi.org/10.1353/jod.2012.0017

Milton, B., Attree, P., French, B., Povall, S., Whitehead, M., \& Popay, J. (2011). The impact of community engagement on health and social outcomes: A systematic review. Community Development Journal, 47(3), 316-334. https://doi.org/10.1093/cdj/bsr043

Miranti, R., \& Evans, M. (2019). Trust, sense of community, and civic engagement: Lessons from Australia. Journal of Community Psychology, 47(2), 254-271. https://doi.org/10.1002/jcop.22119

Nie, N. H., Junn, J., \& Stehlik-Barry, K. (1996). Education and democratic citizenship in America. University of Chicago.

Nizeyumukiza, E., Pierewan, A. C., Ndayambaje, E., \& Ayriza, Y. (2020). Social engagement and retirement satisfaction: Evidence from Indonesia. Journal of Population and Social Studies, 28(3), 221-231. https://doi.org/10.25133/JPSSv28n3.015

Omoto, A. M., Snyder, M., \& Hackett, J. D. (2010). Personality and motivational antecedents of activism and civic engagement. Journal of Personality, 78(6), 1703-1734. https://doi.org/10.1111/j.1467-6494.2010.00667.x 
Piliavin, J. A., \& Siegl, E. (2007). Health benefits of volunteering in the Wisconsin longitudinal study. Journal of Health and Social Behavior, 48(4), 450-464. https://doi.org/10.1177/002214650704800408

Pratono, A. H., Djoemadi, F. R., Avanti, C., Sinaga, N. F. N. T. B., \& Maharani, A. (2019). Civic engagement in the Indonesia health sector. International Journal of Health Governance, 24(4), 244-260. https://doi.org/10.1108/IJHG-10-2018-0057

Putnam, R. D. (1993). Making democracy work: Civic traditions in modern Italy. Princeton University Press.

Putnam, R. D. (1995). Bowling alone: Americas's declining social capital. Journal of Democracy, 6(1), 65-78. https://doi.org/10.1353/jod.1995.0002

Rammstedt, B., \& John, O. P. (2007). Measuring personality in one minute or less: A 10-item short version of the Big Five Inventory in English and German. Journal of Research in Personality, 41(1), 203-212. https://doi.org/10.1016/j.jrp.2006.02.001

Schmitt, C. (2010). Sources of civic engagement in latin America: Empirical evidence from rural Ecuadorian communities. Journal of Development Studies, 46(8), 1442-1458. https://doi.org/10.1080/00220381003599394

Seguin, M. M. (1973). Opportunity for peer socialization in a retirement community. Gerontologist, 13(2), 208-214. https://doi.org/10.1093/geront/13.2.208

Strauss, J., Witoelar, F., \& Sikoki, B. (2016). User's guide for the Indonesia family life survey (Vol. 2, Issue

March). https://www.rand.org/content/dam/rand/pubs/working_papers/WR1100/WR1143z2/RAN D_WR1143z2.pdf

Van Den Bogaard, L., Henkens, K., \& Kalmijn, M. (2014). So now what? Effects of retirement on civic engagement. Ageing and Society, 34(7), 1170-1192. https://doi.org/10.1017/S0144686X13000019

Verba, S., Schloolman, K. L., \& Brady, H. E. (1995). Voice and equality: Civic voluntarism in American. Harvard University Press.

Wray-Lake, L., DeHaan, C. R., Shubert, J., \& Ryan, R. M. (2019). Examining links from civic engagement to daily well-being from a self-determination theory perspective. The Journal of Positive Psychology, 14(2), 166-177. https://doi.org/10.1080/17439760.2017.1388432

You, M., Kim, C., \& Kim, S. (2015). Civic participation and Self-rated health: A Cross-national multilevel analysis using World Value Survey. Journal of Preventive Medicine and Public Health, 48, 18-27. https://doi.org/10.3961/jpmph.14.031

Young, F. W., \& Glasgow, N. (1998). Voluntary social participation and health. Research on Aging, 20(3), 339-362. https://doi.org/10.1177/0164027598203004 